\title{
Development of Mobile Learning for Simulation and Digital Communications
}

\author{
Hazira Fakhrurrozi Amir \\ Program Studi Pendidikan Teknologi dan Kejuruan, Fakultas Teknik, Universitas Negeri Padang, Indonesia \\ e-mail: hazirafakhrurrozi@gmail.com
}

Asrul Huda

Program Studi Pendidikan Teknologi dan Kejuruan, Fakultas Teknik, Universitas Negeri Padang, Indonesia e-mail: asrulhuda@gmail.com

Hasan Maksum

Program Studi Pendidikan Teknologi dan Kejuruan, Fakultas Teknik, Universitas Negeri Padang, Indonesia e-mail: hasan_maksum@yahoo.co.id

\section{A R T I C LE I N F O \\ Article history: \\ 1 Mei 2020 Received in \\ revised form \\ 11 Juni 2020 \\ Accepted 10 Juli 2020 \\ Available online 25 Agustus 2020 \\ Kata Kunci: \\ Mobile learning, \\ simkomdig, android}

Keywords:

Android, mobile learning,

simkomdig

\begin{abstract}
A B S T R A K
Mata pelajaran simulasi dan komunikasi digital di SMKN 1 Singkarak belum memiliki penunjang selain buku teks dan modul. Penelitian ini bertujuan untuk mengembangkan sebuah platform pembelajaran yang praktis dan efektif yang dapat menunjang siswa agar bisa belajar. Penelitian ini menggunakan model pengembangan 4D, dan subjek uji coba dalam penelitian ini siswa kelas X tahun ajaran 2020/2021 yang berjumlah sebanyak 31 orang. Intrumen yang digunakan adalah instrument tes dan angket. Metode yang penelitian yang digunakan adalah pre-experimental. Data yang diperoleh dianalisis menggunakan metode analisis statistik deskriptif kuantitatif. Dari hasil penelitian didapatkan bahwa ketuntasan klasikal mencapai $90 \%$ dan diperoleh rata-rata ditinjau dari gain score siswa dari sebelum dan setelah menggunakan mobile learning adalah 0,49. Simpulkan penelitian ini adalah hasil penilaian baik dari guru maupun siswa menunjukan bahwa mobile learning pada mata pelajaran simulasi dan komunikasi digital dapat dikategorikan sangat praktis, dan efektif
\end{abstract}

\begin{abstract}
A B S T R A C T
Simulation and digital communication subjects at SMKN 1 Singkarak do not have support other than text books and modules. This study aimed to develop a practical and effective learning platform that can support students in learning. This study used a 4D development model, and the trial subjects in this study were 31 students of class X in the 2020/2021 academic year. The instruments used were test and questionnaire instruments. The research method used was pre-experimental. The data obtained were analyzed using quantitative descriptive statistical analysis methods. From the research results, it was found that classical completeness reached $90 \%$ and the average score in terms of the gain score of students before and after using mobile learning was 0.49 . The conclusion of this research is that the results of assessments from both teachers and students show that mobile learning in simulation and digital communication subjects can be categorized as very practical and effective
\end{abstract}

\section{Introduction}

The development of technology and information in the world of education no longer makes students and teachers fixated on textbooks or other conventional media such as television, newspapers and radio. Information technology can be used as a support, even in various cases, the use of information technology can be the main media in learning (Kasatria, 2014; Mu'min, 2019). This change must be put to good use so that students can learn from a variety of sources that are almost unlimited.

Based on observations on February 18 - March 19 2019, simulation learning and digital communication at SMK N 1 Singkarak does not have any support other than text books and modules. The portion of 3 hours of lessons divided for the provision of theory and practicum is still limited. This is certainly an obstacle that must be resolved by providing relevant learning media so that students can study independently outside of independent study hours. This is very unfortunate because digital simulation and communication is one of the important supports in skills development with expertise programs in all skill programs. By studying simulation and digital communication, it can help students at least in general be able to understand the description of the use of technology in accordance with the world of work, and in accordance with the expertise program they are learning. Related to the limited face-to-face time, it requires students to learn independently to repeat the material that has 
been given in the classroom. Students are also required to prepare and repeat lessons in the form of practicum so that students understand the application of the theory that has been learned. So far, the provision of material is still in the form of lectures, demonstrations and is supported by textbooks and exercises both for material as well as for exploring the material or strengthening in practicum. Limited time and conventional material provision which generally tends to be monotonous and teacher-centered are considered less attractive, making students lacking in simulation and digital communication subject matter. Furthermore, simulation and digital communication subjects also encourage the use of technology both in the classroom and outside the classroom through a blended learning approach.

The development of a learning media that can be used as a support for simulated learning and digital communication with a blended-learning approach and can be used on smartphone devices will be able to provide freedom for students to make preparations or repeat the learning with the help of technology. Next, it will be seen how much the contribution of the learning media. This research was planned to be conducted at SMK N 1 Singkarak. Currently, SMK N 1 Singkarak does not have supporting learning media other than textbooks for simulation and digital communication subjects. This is quite unfortunate because the potential use of smartphones can certainly provide alternative learning sources for students and meet Simkomdig's demands that encourage the use of technology in learning combined with face-to-face in class. In addition, the previous average scores were also not satisfied, namely 76 respectively for knowledge and skills with KKM 75. The average learning outcomes of learning simulation and digital communication in semester 1 of 2018/2019 SMKN 1 Singkarak can be seen in Table 1.

Table 1. Average learning outcomes for Simulation and Digital Communication in semester 1 of 2018/2019 SMKN 1 Singkarak

\begin{tabular}{cccc}
\hline \multicolumn{2}{c}{ Knowledge } & \multicolumn{2}{c}{ Skills } \\
\hline Standard Value & Average & Standard Value & Average \\
\hline $\mathbf{7 5}$ & 76 & 75 & 76 \\
\hline
\end{tabular}

Based on the data above, the writer considers that one of the solutions given is the use of technology in education, namely the use of mobile devices to help the learning process. Theoretically, mobile learning which has been firmly established is an innovative tool that has proven successful in developed countries, although in general, mobile devices are used for communication purposes, fortunately some people are starting to consider mobile devices as a major part of pedagogical activities in educational institutions. who have conducive conditions for formal and informal education (El-Hussein \& Cronje, 2010; Jinot, 2019). This is a signal for learning materials to be re-designed, developed, and delivered to fit a learning model that is able to adapt to technological developments. The use of mobile devices in learning or more popularly known as mobile learning directly or indirectly has changed the view of how learning material is delivered.

Learning with mobile learning can be said to be a form of learning that allows students to obtain learning material anywhere and anytime using mobile technology and the internet (Suryanda et al., 2018; Syahbani \& Rosmansyah, 2017). From the above definition, it can be concluded that mobile learning is the use of mobile technology in education that allows access to material without limited location, supports learning effectively and allows students as users to be able to learn independently or simply repeat learning that has been given anywhere and whenever.

Teachers can take advantage of mobile learning with an integrated approach so that students can use mobile learning for independent learning, do homework, repeat lessons and so on (Pratama et al., 2018; Wulandari et al., 2019). Blended learning, which in this case is a combination of classroom learning and the use of mobile learning, can maximize face-to-face advantages in class and online methods, of course with interesting content and tailored to the students' needs. This raises many challenges in the development of m-learning which can really play a role in helping students in learning.

Mobile learning can also be used to create more student-centered learning. By being more student-centered, learning can be designed with attention to student interests and needs as well as human and computer interactions are another consideration where the convenience of using mobile learning media can be designed with attention to the perspective of students as users so that it can be maximally utilized (Hardinata et al., 2018; Setyadi, 2017).

In this development research, the authors have several assumptions about development, including: (1) Students are considered to have owned and are accustomed to using an Android smartphone; (2) Students have support such as laptops or at least have access to school computers outside of class hours to practice subject matter; (3) Students are allowed to bring cell phones to school. (4) Students have access to the internet during school hours. Apart from that, assumptions regarding the things that will become obstacles to development include: (1) Different specifications of smartphone devices that must be adjusted to the needs and circumstances of students; 
(2) Application specifications must be tailored to the needs of students in order to assist students in understanding the subject matter; (3) Limitations on collaboration features that are not yet available between teachers and students or fellow students.

Previous research that are relevant to this research include: (1) research conducted by (Ibrahim \& Ishartiwi, 2017) who get the results that Android-based mobile learning media is effective in improving student learning outcomes. (2) research conducted by (Cecep et al., 2019) who get the results that the mobile learning-based quick math application as a support for mathematics learning in high school is very feasible to be tested because it meets the very good assessment criteria. (3) Research conducted by (Juniarti \& Gustiana, 2019) who get the results that the existence of mobile learning-based learning resources can learn early childhood games effectively and efficiently. (4) Research conducted by (Khomarudin et al., 2018) who get the results that the resulting androidbased m-learning media products get results in the category of very effective, feasible and can be used in learning artificial intelligence courses.

Based on several previous studies, the novelty of this research is the development of mobile learning which includes simulation and digital communication subject matter. This study aimed to develop a mobile learning that is practical and effective and is able to support the student learning process by providing alternative learning resources in simulation and digital communication subjects at SMKN 1 Singkarak. From this research, it is hoped that a mobile learning can contain material and exercises in the form of text or media such as audio and video. Research is uploaded to the playstore so that it can make it easier for students to find applications. Distribution is also carried out for source code through version controlling which uses Github in addition to monitoring development. Research does not only focus on how the product is developed to become a finished product, but also looks at how the effectiveness of the product developed in its implementation so that a product can function properly.

\section{Method}

The research method used in this research was Pre-Experimental by giving pre-test and post-test to students and seeing how much the student gain score after being given treatment. The test subjects in this study were 31 students of class X SMKN 1 Singkarak in the academic year 2020/2021. Class X was chosen because simulation and digital communication were only studied in class X. The data used in this study were primary data. Data obtained directly from the opinions of experts, student and teacher responses about the usefulness of mobile learning through a questionnaire given and then analyzed. The use of primary data in this study aims to obtain first-hand information that does not exist in the form that has been collected either in written form or digital data from previous research.

This development model uses the 4-D modeling technique which consists of 4 steps, namely Define, Design, Develop and Disseminate (Wulandari et al., 2019). This model was chosen for research because the development model has a systematic process, according to the problems underlying this research. By conducting curriculum analysis and student analysis, it is hoped that this model can be developed mobile-based learning that is practical, valid and effective and in increasing student activity and learning outcomes.

The instruments used in this research include validation sheets which are used to determine the validity of mobile learning by experts. Before carrying out the research, the researcher arranged the instruments by following the instrument grid. The stages in compiling a validation instrument include: (a) compiling a grid on the questionnaire, (b) analyzing subvariables so that they can be used as indicators, (c) Determining the number of question items needed for an indicator, (d) Formulating questions in accordance with predefined indicators. Next is a practicality instrument that is used to measure the practicality of the media for students and teachers as users. The preparation of this practicality sheet is the same as in the preparation of the validation sheet as described above. The effectiveness of this study is measured from the results of learning tests using mobile learning. Learning outcomes are obtained by providing learning treatment using mobile learning which is valid and practical by looking at the student's gain score.

The data analysis technique used is quantitative statistical analysis which is used to analyze the data for calculating the effectiveness, practicality of using mobile learning at SMKN 1 Singkarak in simulation and digital communication subjects.

\section{Result and Discussion}

From the research, it was found that classical completeness reached $90 \%$ which means that the learning process was successful. Learning is said to be complete and effective if $85 \%$ of students achieve absorption, namely $\geq$ KKM (minimum completeness criteria). The effectiveness of simulated mobile learning and digital communication is also seen from the students' gain score before and after using mobile learning is 0.49 which can be categorized as moderate. Based on these data, namely classical completeness and gain score, mobile learning 
simulation and digital communication applied at SMKN 1 Singkarak are effective. These results indicate a positive influence from the use of mobile learning at SMKN 1 Singkarak on simulation and digital communication subjects. Class X Class Students' Classical Completeness can be seen in Table 2.

Table 2. Classical completeness of Class X

\begin{tabular}{ccc}
\hline Standard Value & Student Total & Percentage \\
\hline$<\mathbf{7 5}$ & 3 & $10 \%$ \\
$\geq \mathbf{7 5}$ & 27 & $90 \%$ \\
\hline Total & 30 & $100 \%$
\end{tabular}

The results above indicate that the developed mobile learning can be further developed. Research relevant to these results is (Akmal \& Susanto, 2018) which shows that which indicates that there is a high enough increase from the average value of the pre-test to the post-test after using the learning application with a ratio of 20.48 or an increase of $41.72 \%$. Related to other relevant research results is research by (Purbasari et al., 2019) who get the results of social studies learning media based on mobile learning applications with a social constructivism approach can be further developed.

Development is carried out by carrying out stages adapted to the 4D model. The first stage is the defining stage which is carried out for the first time by conducting interviews with the teacher by paying attention to the implementation of PBM. Subject teachers also provide learning tools used to design mobile learning. Next is a needs analysis that found several obstacles for students to study independently both as preparation and to repeat learning because students only depend on limited numbers of textbooks, so that students have difficulty repeating lessons. The delivery of teaching materials is only teacher-centered, which currently uses PowerPoint in its delivery. Student analysis shows a learning media that is suitable for the student's condition, namely a mobile learning that allows students to access material offline and if connected to the internet, students can access video tutorials for certain materials. The material in this study has been adjusted to the needs of students who are still not covered in the training during the PBM. The material is presented in a summary form that can be accessed without a network and tutorials in the form of videos that can be accessed by students through a mobile learning application developed if connected to the internet network (Akmal \& Susanto, 2018).

At the design stage, it is carried out by paying attention to the achievement of the material contained in the application which is arranged in a summary form so that it can be used as learning support. This is so that students have provisions before starting learning and can repeat learning. Material with more practice, such as the material for word processing applications, made video tutorials. Word processing material is also used as material that is tested so that the material is more complete than other materials. However, other materials should still be considered for the achievement of the material by still incorporating material into the exercises provided with the same number of questions (Efriyanti \& Annas, 2020).

The design is arranged in the form of Tab View to display content. Navigation is at the bottom which contains the menu on the application. The tab is the Home menu which is the start page containing a list of learning materials and tools, Video tutorials that contain video tutorials of one of the materials from each chapter, useful evaluations to see how much student mastery of learning material, help and a menu containing information regarding the application. The main page template can be seen in Figure 1.

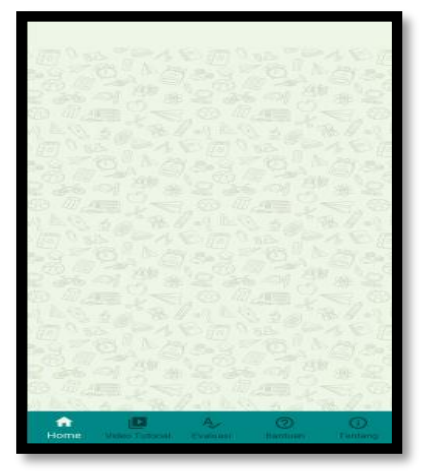

Figure 1. Main Page Template 
Development is carried out using Android Studio 3.5 for application development. The development process is also carried out by creating a repository on github as a backup. To design the background and several icons made using Corel Draw and Photoshop. The draft for the content is finalized before creating the application. Generally, the application consists of Main Page, Material Page, Quiz Page, About Page and Help Page. The use of version controlling really helps the author in seeing the development of the application. Every time there is a change in the project, the author uploads the source code to Github which aims as a version controlling and backup media. The use of version controlling also makes it easier for writers to work on multiple computers easily without having to do the copy and paste process repeatedly. The version controlling page on github can be seen in Figure 2 .

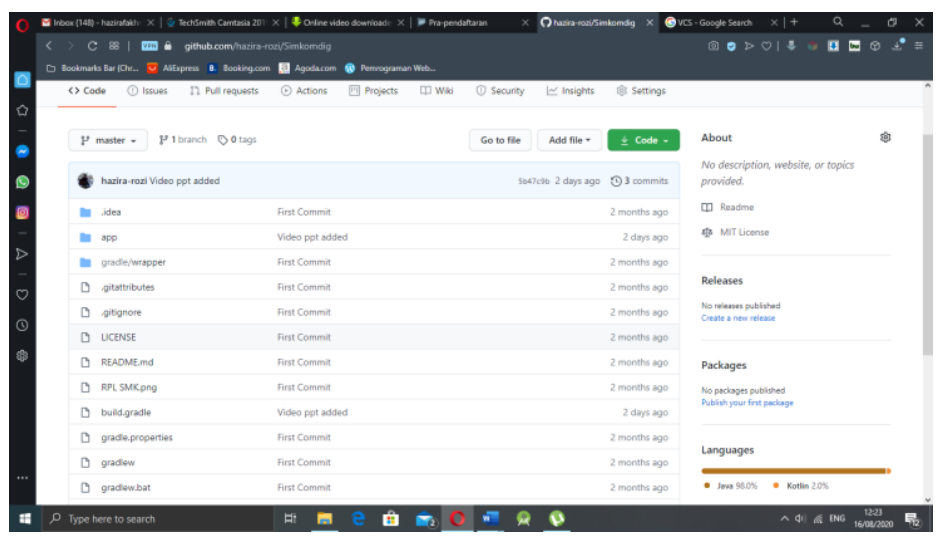

Figure 2. The Version Controlling page on Github

Dissemination is carried out by implementing the simulation learning process and digital communication and uploading the application to the Playstore so that the application can be downloaded by students. Furthermore, the authors provide socialization to students regarding the use of the application. During this process, students enthusiastically listen to explanations of application usage and install applications on their respective devices. In addition to distributing the application, the author also distributes source code to Github in the hope that there will be input from fellow developers and can be a learning resource for students, especially for students of SMKN 1 Singkarak.

The length of time for Google's approval for uploaded applications is an obstacle so that the author distributes it to students in apk form. This is related to Google's policy which gives priority to existing applications and applications that provide references to Covid 19. Applications were only accepted on August 21, 2020.

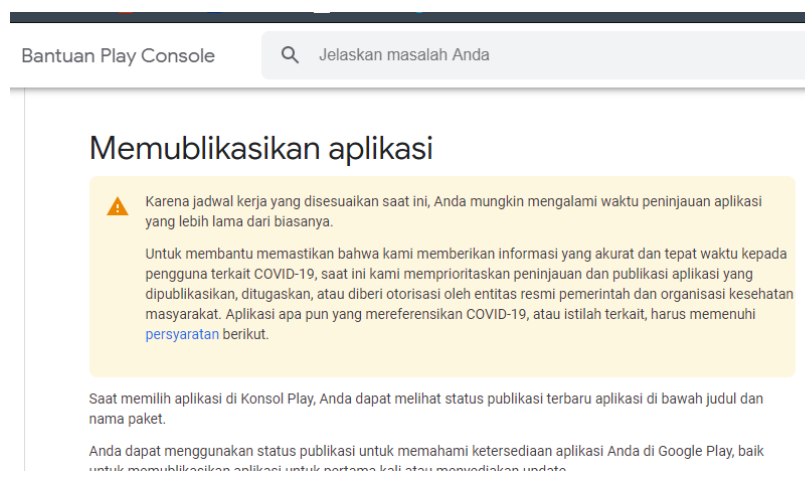

Figure 3.Google Help Page About Application Publication Constraints

Learning with mobile learning can be said to be a form of learning that allows students to obtain learning material anywhere and anytime using mobile technology and the internet. (Suryanda et al., 2018; Syahbani \& Rosmansyah, 2017). Mobile learning is the use of mobile technology in education that allows access to material without limited location, supports learning effectively and allows students as users to be able to learn independently or simply repeat learning that has been given anywhere and anytime (Listyorini \& Widodo, 2013; Taufiq \& Amalia, 2017) 
This mobile learning media has several advantages, namely (1) the presentation of material in mobile learning products is very easy to operate, (2) mobile learning products are interactive so that they can actively attract students' attention, (3) mobile learning products are packaged in files apk so it's easy to use (Ibrahim \& Ishartiwi, 2017; Rasyid et al., 2020).

Mobile learning can also be used to create more student-centered learning. By being more student-centered, learning can be designed with attention to student interests and needs as well as human and computer interactions are another consideration where the convenience of using mobile learning media can be designed with attention to the perspective of students as users so that it can be maximally utilized (Hardinata et al., 2018; Setyadi, 2017).

Previous studies that are relevant to this research include: (1) research conducted by (Ibrahim \& Ishartiwi, 2017) who get the results that Android-based mobile learning media is effective in improving student learning outcomes. (2) research conducted by (Cecep et al., 2019) who get the results that the mobile learning-based quick math application as a support for mathematics learning in high school is very feasible to be tested because it meets the very good assessment criteria. (3) Research conducted by (Juniarti \& Gustiana, 2019) who get the results that the existence of mobile learning-based learning resources can learn early childhood games effectively and efficiently. (4) Research conducted by (Khomarudin et al., 2018) who get the results that the resulting androidbased m-learning media products get results in the category of very effective, feasible and can be used in learning artificial artificial intelligence.

Based on several previous studies, the novelty of this research is the development of mobile learning which includes simulation and digital communication subject matter. From this research, it is hoped that a mobile learning can contain material and exercises in the form of text or media such as audio and video. Research is uploaded to the playstore so that it can make it easier for students to find applications. Distribution is also carried out for source code through version controlling which uses Github in addition to monitoring development. Research does not only focus on how the product is developed to become a finished product, but also looks at how the effectiveness of the product developed in its implementation so that a product can function properly.

\section{Conclusion}

From the developments that have been carried out, mobile learning has been produced that supports simulation learning and digital communication at SMKN 1 Singkarak. The development is carried out with the 4D development model, namely define, design, develop and dissiminate. The teaching materials contained in the application can be said to be practical after testing on simulation and digital communication subject teachers and after being used by students. The results of the assessment from both teachers and students show that mobile learning can be categorized as very practical. This research can be developed in other subjects because besides making it easier for teachers and students, mobile learning can also be a solution for learning from home because the applications developed can be accessed even without using an internet connection. Students are no longer limited to one learning resource because they can use mobile learning. For SMKN 1 Singkarak, especially the competence of software engineering expertise is expected to be able to make the results of this research as a reference for future development and can be used as a source of learning by utilizing the documentation from this research.

\section{References}

Akmal, H., \& Susanto, H. (2018). Efektivitas Penggunaan Aplikasi Pembelajaran Berbasis Mobile Smartphone Sebagai Media Pengenalan Sejarah Lokal Masa Revolusi Fisik Di Kalimantan Selatan Pada Siswa Sekolah Menengah Atas. Jurnal HISTORIA, 6(2), 197-206.

Cecep, C., Mutaqin, A., \& Pamungkas, A. S. (2019). Pengembangan Modul Quick Math Berbasis Mobile Learning sebagai Penunjang Pembelajaran Matematika di SMA. Prisma Sains: Jurnal Pengkajian Ilmu Dan Pembelajaran Matematika Dan IPA IKIP Mataram, 7(2), 148-159. https://doi.org/10.33394/j-ps.v0i0.1761

Efriyanti, L., \& Annas, F. (2020). Aplikasi Mobile Learning Sebagai Sarana Pembelajaran Abad 21 Pada Era Revolusi Industri 4.0. JURNAL EDUCATIVE: Journal of Educational Studies, 5(1), 1-40. https://doi.org/http://dx.doi.org/10.30983/educative.v5i1.3132

El-Hussein, M. O. M., \& Cronje, J. C. (2010). Defining Mobile Learning in the Higher Education Landscape. Educational Technology \& Society, 13(3), 12-21.

Hardinata, R., Murwitaningsih, S., \& Amirullah, G. (2018). Pengembangan Mobile Learning Sistem Koordinasi Berbasis Android. Bioeduscience, 2(1), 53-58. https://doi.org/10.29405/j.bes/53-58121334 
Ibrahim, N., \& Ishartiwi, I. (2017). Pengembangan Media Pembelajaran Mobile Learning Berbasis Android Mata Pelajaran IPA Untuk Siswa SMP. Refleksi Edukatika: Jurnal Ilmiah Kependidikan, 8(1), 80-88. https://doi.org/10.24176/re.v8i1.1792

Jinot, B. L. (2019). An Evaluation of a Key Innovation: Mobile Learning. Academic Journal of Interdisciplinary Studies, 8(2), 39-45.

Juniarti, Y., \& Gustiana, E. (2019). Pengembangan Sunber Belajar Bermain Berbasis Mobile Learning. JPE (Jurnal Pendidikan Edutama), 6(1), 37-42. https://doi.org/http://dx.doi.org/10.30734/jpe.v6i1.289

Kasatria, R. J. (2014). Pengembangan Teknologi Informasi Mobile Learning Fakultas Teknik Universitas Diponegoro Berbasis Android. Jurnal Teknologi Dan Sistem Komputer, 2(4), 241-248. https://doi.org/https://doi.org/10.14710/jtsiskom.2.4.2014.241-248

Khomarudin, A. N., Efriyanti, L., \& Tafsir, M. (2018). Pengembangan Media Pembelajaran Mobile Learning Berbasis Android Pada Mata Kuliah Kecerdasan Buatan. Journal Educative: Journal of Educational Studies, 3(1), 72-87. https://doi.org/10.30983/educative.v3i1.543

Listyorini, T., \& Widodo, A. (2013). Perancangan Mobile Learning Mata Kuliah Sistem Operasi Berbasis Android. Jurnal SIMETRIS, 3(1), 25-30. https://doi.org/10.1017/CBO9781107415324.004

Mu'min, U. A. (2019). Peran Teknologi Informasi Dalam Bidang Pendidikan (E-education). Al-Afkar, Journal for Islamic Studies, 2(1), 104-119. https://doi.org/10.31219/osf.io/ycfa2

Pratama, R. A., Ulfa, S., \& Kuswandi, D. (2018). Mobile Learning Berbasis Game Based Learning Pelajaran Matematika Pokok Bahasan Bangun Ruang Sisi Datar. Jurnal Pendidikan: Teori, Penelitian, Dan Pengembangan, 3(6), 771-777. https://doi.org/http://dx.doi.org/10.17977/jptpp.v3i6.11167

Purbasari, I., Ismaya, E. A., Suryani, N., \& Djono. (2019). Media Pembelajaran Ilmu Pengetahuan Sosial Berbasis Aplikasi Mobile Learning bagi Siswa Sekolah Dasar. Sejarah, Budaya Dan Pengajaran, 2015, 97-106. https://doi.org/10.17977/um020v13i12019p97

Rasyid, A., Gaffar, A. A., \& Utari, W. (2020). Efektivitas Aplikasi Mobile Learning Role Play Games (RPG) Maker Mv Untuk Meningkatkan Kemampuan Berpikir Kritis. Jurnal Mangifera Edu, 4(2), 107-115.

Setyadi, D. (2017). Pengembangan Mobile Learning Berbasis Android Sebagai Sarana Berlatih Mengerjakan Soal Matematika. Satya Widya, 33(2), 87-92. https://doi.org/10.24246/j.sw.2017.v33.i2.p87-92

Suryanda, A., Ernawati, E., \& Maulana, A. (2018). Pengembangan Modul Multimedia Mobile Learning Dengan Android Studio 4.1 Materi Keanekaragaman Hayati Bagi Siswa Sma Kelas X. Biosfer: Jurnal Pendidikan Biologi, 9(1), 55-64. https://doi.org/10.21009/biosferjpb.9-1.9

Syahbani, M. H., \& Rosmansyah, Y. (2017). Pengembangan Mobile Collaborative Learning System Menggunakan Kerangka Kerja Zachman dan DICE. Jurnal Informatika: Jurnal Pengembangan IT Poltek Tegal, 2(2), 4752. http://ejournal.poltektegal.ac.id/index.php/informatika/article/view/515

Taufiq, M., \& Amalia, A. V. (2017). the Development of Science Mobile Learning With Conservation Vision Based on Android App Inventor 2. Unnes Science Education Journal, 6(1), 1472-1479. https://doi.org/10.15294/usej.v6i1.13179

Wulandari, D. A., Wibawanto, H., Suryanto, A., \& Murnomo, A. (2019). Pengembangan Mobile Learning berbasis Android pada Mata Pelajaran Rekayasa Perangkat Lunak di SMK Sultan Trenggono Kota Semarang. Jurnal Teknologi Informasi Dan Ilmu Komputer, 6(5), 577. https://doi.org/10.25126/jtiik.201965994 